\title{
PENGARUH KUALITAS PRODUK, DESAIN PRODUK DAN HARGA PRODUK TERHADAP KEPUTUSAN PEMBELIAN MEBEL PADA COLLECTION FURNITURE DI PONDOK BAMBU.
}

\author{
Muhammad Ridwan \\ Sintia Desi \\ Fakultas Ekonomi dan Bisnis Jurusan Manajemen \\ Universitas Islam As-Syafiiyah, Jakarta. \\ m_ried88@yahoo.com \\ sintiadesiii@gmail.com
}

\begin{abstract}
The purpose of this study is to determine the effect of product quality, product design and price on furniture purchase decisions on Collection Furniture in Pondok Bambu. The sampling technique used is Purposive Samples. The sample in this study amounted to 96 respondents. Methods of data collection using questionnaires distributed to consumers of furniture buyers Collection Furniture in Pondok Bambu and analytical techniques used are multiple linear regression. The results show that 1). Product quality is the highest variable in influencing purchasing decisions Furniture on Collection Furnture in Pondok Bambu with products with durable texture. 2). Design becomes the second variable that influences purchasing decisions Furniture On Collection Furniture in Pondok Bambu, shows that elegant models in product design can influence consumers to buy back. 3). Price is the lowest variable affecting purchasing decisions of Furniture on Collection Furniture di Pondok Bambu.
\end{abstract}

Keywords: product quality, product design, price and purchasing decisions

\section{PENDAHULUAN}

\section{Latar Belakang}

Pembangunan industri saat ini peranannya sangat besar di dalam perkembangan dan pertumbuhan pembangunan, maka industri mebel Indonesia masih memiliki nama di pentas perdagangan dunia (Arief, 2014). Di Indonesia, khususnya DKI Jakarta memiliki sentra - sentra industri mebel yang memiliki kretivitasnya lebih tinggi, baik berbentuk bahan hukum maupun perorangan (home industri) sebagai perajin mebel.

Industri mebel (Furniture) merupakan industri yang mengolah bahan baku atau bahan setengah jadi yang meliputi kayu, rotan, dan bahan alami lainnya menjadi produk barang jadi yang bisa disebut dengan mebel (Furniture) yang mempunyai nilai tambah dan manfaat yang lebih tinggi..

Salah satu produsen mebel di Jakarta Timur adalah Collection Furniture, daerah Pondok Bambu, Duren Sawit, Jakarta timur. Collection Furniture didirikan oleh Malharyatin pada tahun 2000. Perusahaan ini berfokus pada furniture berbahan multiplek, plywood dan kayu jati untuk menjaga kualitas produk. Mebel yang diproduksi oleh Collection Furniture ini tergolong pada mebel kelas premium yang bergaya modern maupun minimalis.

Namun demikian, adanya persaingan dari beberapa perusahaan yang sejenis, berdampak pada penjualan yang menurun dari tahun ke tahun. Berdasarkan data 
penjualan mebel, Collection Furniture di Pondok Bambu tahun 2014 - 2018 sebagai berikut:

Tabel 1

Penjualan mebel Collection Furniture

Tahun 2014 - 2018

\begin{tabular}{|c|cc|c|}
\hline Tahun & \multicolumn{2}{|c|}{ Omset } & $\begin{array}{c}\text { Presentasi } \\
\text { perubahan omset } \\
\text { penjualan }\end{array}$ \\
\hline 2014 & $\mathrm{Rp}$ & $609,000,000$ & - \\
\hline 2015 & $\mathrm{Rp}$ & $508,000,000$ & $-19.88 \%$ \\
\hline 2016 & $\mathrm{Rp}$ & $499,000,000$ & $-1.80 \%$ \\
\hline 2017 & $\mathrm{Rp}$ & $478,000,000$ & $-4.39 \%$ \\
\hline 2018 & $\mathrm{Rp}$ & $387,000,000$ & $-23.51 \%$ \\
\hline
\end{tabular}

Sumber data : Collection Furniture, Jakarta, 2018.

Dari tabel diatas penjualan mebel pada mebel Collection Furniture mengalami penurunan. Penurunan tersebut disebabkan oleh beberapa hal diantaranya kurangnya bahan baku, rendahnya kualitas produk dibanding produk lainnya yang sejenis, kurang berkembangnya Desain Poduk, lebih mahalnya produk tersebut dibanding daya produk perusahaan lain. Hal ini berdampak pada keputusan pembelian yang rendah.

Sebagaimana firman Allah dalam al-Qur'an surat Al Hujurat ayat 6

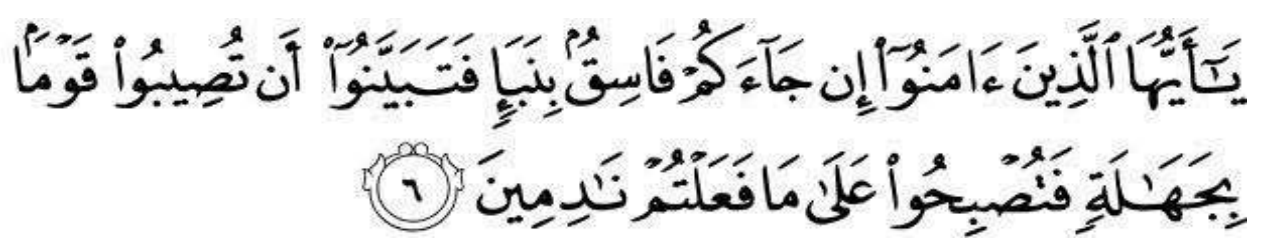

Artinya : "Hai orang-orang yang beriman, jika datang kepadamu orang fasik membawa suatu berita, akan periksalah dengan teliti agar kamu tidak menimpakan suatu musibah kepada suatu kaum tanpa mengetahui keadaanya yang menyebabkan kamu menyesal atas perbuatanmu."

Dari ayat diatas dapat diketahui bahwa sebagai umat muslim hendaknya berhati-hati dalam menerima suatu berita atau informasi. Ayat ini juga dapat disandarkan dengan sikap hati-hati umat Islam dalam membuat keputusan untuk mengkonsumsi atau menggunakan produk. Sebelum memutuskan suatu produk furniture hendaknya konsumen mengetahui terlebih dahulu keadaan produk tersebut. Sehingga memahami furniture seperti apa yang dapat menyelesaikan kebutuhan konsumen. Hendaknya terlebih dahulu mencari informasi mengenai kuaitas produk, desain, dan harga. Hal inilah yang menjadi alasan betapa pentingnya mencari informasi terkait suatu infomasi atau berita yang ada.

Hasil penelitian terdahulu yang dilakukan Jakson R.S. Weenas (2013), yang berjudul Kualitas produk, harga, promosi dan kualitas layanan terhadap keputusan pembelian springbed comforta. Menunjukan bahwa kualitas produk, harga, promosi, kualitas layanan maka berpengaruh positif dan signifikan terhadap keputusan pembelian dengan nilai sebesar 0,49. Dan penelitian oleh Nur Achidah, M Mukey Warso, Leonardo budi 
hasiolan (2016), yang berjudul Pengaruh promosi, Harga dan Desain terhadap keputusan pembelian sepeda motor Mio GT. Menunjukan bahwa promosi, harga, dan desain berpengauh positif dan signifikan terhadap keputusan pembelian dengan nilai 57,205.

Dari penjelasan atau latar belakang diatas maka peneliti tertarik untuk meneliti Pengaruh Kualitas Produk, Desain Produk Dan Harga Produk Terhadap Keputusan Pembelian Mebel Pada Collection Furniture Di Pondok Bambu".

\section{Perumusan Masalah}

Berdasarkan latar belakang masalah diatas, maka permasalahan yang di teliti pada penelitian ini adalah :

1. Apakah Kualitas Produk berpengaruh terhadap Keputusan Pembelian Collection Furniture?

2. Apakah Desain Produk berpengaruh terhadap Keputusan Pembelian Collection Furniture?

3. Apakah Harga Produk berpengaruh terhadap Keputusan Pembeliaan Collection Furniture?

4. Apakah Kualitas Produk, Desain Produk dan Harga Produk berpengaruh terhadap Keputusan Pembelian Collection Furniture ?

\section{Tujuan Penelitian}

Tujuan dari penelitian ini sebagai berikut :

1. Untuk mengetahui pengaruh Kualitas Produk terhadap Keputusan Pembelian Collection Furniture.

2. Untuk mengetahui pengaruh Desain Produk terhadap Keputusan Pembelian Collection Furniture.

3. Untuk mengetahui pengaruh Harga Produk terhadap Keputusan Pembeliaan Collection Furniture.

4. Untuk mengetahui pengaruh Kualitas Produk, Desain Produk dan Harga Produk terhadap Keputusan Pembelian Collection Furniture.

\section{Manfaat Penelitian}

Penelitian ini diharapkan akan menarik nilai manfaat bagi semua yang membacanya, antara lain :

1. Manfaat praktis

1. Bagi perusahaan, sebagai sumber informasi mengenai faktor - faktor yang mempengaruhi keputusan pembelian. Dan memberikan masukan dalam mengembangkan usahanya dan mengembangkan strategi pemasaran dalam menghadapi persaingan.

2. Bagi Akademik, dapat menjadi bahan masukan dan perbandingan bagi peneliti lainnya maupun memperluas wawasan dan pengetahuan tentang kualitas produk, desain produk, dan harga terhadap keputusan pembelian.

2. Manfaat teoritis

1. Hasil penelitian ini dapat menjadi landasan dalam pengembangan pembelajaran atau penerapan pembelajaran lebih lanjut. Selain juga menjadi sebuah nilai tambah dibidang pemasaran khususnya kualitas produk, desain produk dan harga terhadap keputusan pembelian.

2. Bagi peneliti, untuk menambah wawasan dan ilmu pengetahuan, serta dapat digunakan sebagai pembanding dalam penelitian di bidang pemasaran 
khususnya tentang kualitas produk, desain produk dan harga terhadap keputusan pembelian

\section{TINJAUAN TEORITIS}

\section{Keputusan Pembelian}

Menurut Kotler dan Amstrong ( 2016 ) keputusan pembelian adalah bagian dari perilaku konsumen yaitu studi tentang bagaimana individu, kelompok, dan organisasi memilih, membeli, mengguanakan, dan bagaimana barang, jasa, ide atau pengalaman untuk memuaskan kebutuhan dan keinginan mereka"

Sedangkan menurut Suharno ( 2010:96), menyatakan bahwa keputusan pembelian konsumen adalah Tahap di mana pembeli telah menentukan pilihannya dan melakukan pembelian produk, serta mengkonsumsinya pengambilan keputusan oleh konsumen untuk melakukan pembelian suatu produk diawali oleh adanya kesadaran atas kebutuhan dan keinginan. Selanjutnya jika sudah disadari adanya kebutuhan dan keinginan, maka konsumen akan mencari informasi mengenai keberadaan produk yang diinginkannya.

Dari beberapa pendapatan para ahli diatas dapat disimpulkan bahwa Keputusan pembelian adalah salah satu bentuk perilaku konsumen didalam menggunakan atau mengkonsumsi suatu produk. Didalam membeli atau memakai suatu produk tertentu untuk melakukan pengambilan suatu keputusan, konsumen akan melalui suatu proses dimana proses tersebut merupakan gambaran dari bagaimana konsumen menganalisis berbagai macam input untuk mengambil keputusan dalam melakukan pembelian.

\section{Proses Keputusan Pembelian}

Proses pembelian dimulai jauh sesudah pembelian yang sesungguhnya. Pemasaran harus memberi perhatian kepada semua tingkatan proses, dan bukan hanya kepada tingkat keputusan pembelian saja. Menurut Ginting (2012:48), terdapat lima tingkatan yang dilewati pembelian dalam mencapai keputusan pembeliannya, yakni pengenalan kebutuhan, pencarian informasi, penilaian pilihan, keputusan pembelian dan perilaku pasca beli.

Berdasarkan uraian tersebut, maka dapat digambarkan proses keputusan pembelian yaitu :

\section{Gambar 2.1}

Proses Keputusan Pembelian

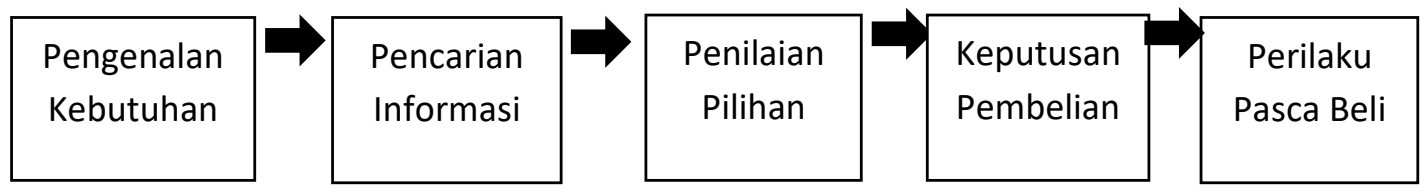

Sumber : Ginting (2012:48)

Gambar 2.1 memperlihatkan bahwa konsumen menapaki lima tingkatan pada setiap melakukan pembelian dan kenyataannya konsumen sering melompat melewati atau membalik pada tingkatan tertentu. 


\section{Kualitas Produk}

Menurut Kotler dan Amstrong ( 2015 ) Kualitas produk adalah kemampuan suatu produk untuk melakukan fungsi - fungsinya. Kemampuan ini meliputi daya tahan, kehandalan, ketelitian yang dihasilkan, kemudahan operasikan, diperbaiki, dan atribut lain yang berharga pada profuk secara keseluruhan"

Tantangan paling besar dihadapi oleh setiap perusahaan adalah masalah pengembangan produk. Pengembangan produk dapat dilakukan oleh personalia dalam perusahaan dengan cara mengembangkan produk yang sudah ada. Di samping itu juga dapat menyewa para peneliti guna menciptakan produk baru dengan model-model yang sesuai. Perusahaan yang tidak mengadakan atau tidak mampu menciptakan produk baru akan menghadapi resiko seperti penurunan volume penjualan, karena munculnya pesaing yang lebih kreatif, adanya perubahan selera konsumen, munculnya teknologi baru dalam proses produksi (Asshiddiqi, 2013).

\section{Indikator Kualitas Produk}

Indikator kualitas produk yang digunakan dalam penelitian ini berdasarkan pada Kotler (Supriyadi at,all 216:2) sebagai berikut :

1. Kinerja produk .

2. Penampilan.

3. Kemudahan mendapatkan produk

4. Keandalan produk

5. Ketahanan kualitas

6. Produk tidak cacat .

\section{Desain Produk}

Menurut Kotler dan Amstrong (2015) desain produk adalah penampilan produk tertentu, desain yang baik dapat memeberikan konstribusi dalam hal kegunaan produk dan juga penampilannya. Desain yang baik dapat menarik perhatian, meningkatkan kinerja produk biaya produksi dan memberikan keunggulan bersaing di pasar sasaran"

Desain juga akan berkontribusi terhadap tercapainya tujuan perusahaan, desain lebih dari sekedar kulit luar, desain adalah jantung produk. Desain yang baik tidak hanya mempunyai andil dalam penampilan produk tetapi juga dalam manfaatnya (Hamidah, 2013). Desain sangat penting terutama pembuatan dan pemasaran jasa eceran, busana, barang kemasan, dan peralatan tahan lama. Desainer harus menemukan berapa banyak yang diinvestasikan dalam bentuk pengembangan fitur, kinerja, kesesuain, ketahanan, keandalan, kemudahan perbaikan, dan gaya.

Bagi perusahaan, produk yang dirancang dengan baik adalah produk yang mudah dibuat dan didistribusikan. Bagi pelanggan, produk yang dirancang dengan baik adalah produk yng penampilannya menyenangkan dan mudah dibuka, dipasang, digunakan, diperbaiki dan disingkirkan. Desainer harus memperhitungkan semua faktor ini. Pendapat atas desain yang baik sangat meyaknkan terutama bagi perusahaan produk konsumen yang lebih kecil dan perusahaan pemula yang tidak mempunyai anggara iklan yang besar (Ginting, 2012).

\section{Harga Produk}

Harga merupakan salah satu faktor prsaingan dalam memasarkan produk. Setiap perusahaan berlomba - lomba menawarkan harga yang menarik agar konsumen ingin membeli produk yang ditawarkan. Menurut Fandy Tjiptono (2016) Harga merupakan 
satu - satunya unsur bauran pemasaran yang mendatangkan pemasukan atau pendapatan bagi perusahaan tersebut.

Menurut Nur Achidah ( 2016) Harga adalah pengorbanan ekonomis yang dilakukan pelanggan untuk memperoleh produk dan jasa. Selain itu harga salah satu faktor penting untuk konsumen dalam mengambil keputusan untuk melakukan transaksi atau tidak"

Kualitas dilihat dari beberapa aspek produk tersebut dibuat, sedangkan tanggapan emosi lebih berkaitan perasaan konsumen setelah membeli suatu produk. Dalam membeli suatu produk konsumen tidak hanya mempertimbangkan kualitasnya saja, tetapi juga memikirkan kelayakan hargnya (Achidah, 2016).

\section{Penelitian Terdahulu}

Penelitian ini dibuat berdasarkan hasil penelitian yang dilakukan oleh penelitipeneliti sebelumnya yang diringkas dalam tabel berikut ini :

1. Penelitian yang dilakukan oleh Fuad Asshiddieqi, Mudiantoro (2012) yang berjudul "Analisis pemgaruh harga, desain produk dan citra merek terhadap keputusan pembelian pada Produk Crooz di Distro Ultraa Store”. Menunjukan bahwa promosi, harga, dan desain berpengauh positif dan signifikan terhadap keputusan pembelian dengan nilai 57,205.

2. Penelitian yang dilakukan oleh Siti Hamidah dan desi anita (2013) yang berjudul "Analisis Persepsi Citra Merek, Desain, Fitur dan Pengaruhnya Terhadap Keputusan Pembelian Produk Handphone Samsung Berbasis Android" bersamasama menunjukkan angka sebesar 0,166. variabel-variabel tersebut memiliki pengaruh positif dan signfikan terhadap keputusan pembelian produk Handphone Samsung dengan nilai 0,166 .

3. Penelitian yang dilakukan oleh Jakson R.S Weenas (2013) yang berjudul "Kualitas Produk, Harga, Promosi dan Kualitas layanan pengaruhnya terhadap keputusan pembelian springbed comforta" Menunjukan bahwa kualitas produk, harga, promosi, kualitas layanan maka berpengaruh positif dan signifikan terhadap keputusan pembelian dengan nilai sebesar 0,49.

4. Penelitian yang dilakukan oleh Lidya Mongi (2013) yang berjudul "Kualitas Produk, strategi promosi dan harga pengaruh terhadap pembelian kartu simpati telkomsel". Menunjukan bahwa kualitas produk, strategi promosi dan harga berpengaruh signifikan terhadap keputusan pembelian kartu Simpati Telkomsel di kota Manado dengan nilai 0.038 .

5. Penelitian yang dilakukan oleh Nur Achida, M mukery Warso, Leonardo Budi Hasiolan (2016) yang berjudul "pengaruh Promosi, Persepsi Harga, dan Desain Terhadap keputusan pembelian sepeda motor mio GT". Menunjukan bahwa promosi, harga, dan desain berpengauh positif dan signifikan terhadap keputusan pembelian dengan nilai 57,205.

\section{Hipotesis}

Hipotesis adalah jawaban sementara terhadap rumusan masalah penelitian, oleh karena itu ruusan masalah penelitian biasanya disusun dalam bentuk kalimat pertanyaan (Siregar, 2013). Hipotesis yang diajukan dalam penelitian ini adalah sebagai berikut : 


\section{Pengaruh kualitas produk $\left(\mathrm{X}_{1}\right)$ terhadap Keputusan Pembelian (Y)}

Kualitas produk adalah salah satu sarana postioning utama pemasar. Kualitas mempunyai dampak langsung pada kinerja produk atau jasa, oleh karena itu, kualitas berhubungan erat dengan nilai dan kepuasan pelanggan (Kotler dan Amstrong,2008:272). Kualitas produk berarti kualitas kinerja kemampuan produk untuk melaksanakan fungsinya. Perusahaan jarang berusaha menawarkan tingkat kualitas kinerja yang setinggi mungkin sedikit pelanggan yang menginginkan atau mampu menjangkau tingkat kualitas tinggi yang ditawarkan.

Hal tersebut dapat dibuktikan melalui penelitian yang telah dilakukan oleh Mongi, Weenas dan Asshiddiqi (2013) menyatakan bahwa variabel kualitas produk berpengaruh positif dan signifikan terhadap variabel keputusan pembelian.

H1 = Ada pengaruh positif dan signifikan antara kualitas produk terhadap keputusan pembelian.

\section{Pengaruh Desain Produk $\left(\mathrm{X}_{2}\right)$ terhadap keputusan pembelian $(\mathrm{Y})$}

Desain adalah konsep yang lebih besar daripada gaya (Kotler dan Armstrong,2008:273). Desain produk dapat mempengarui keputusan pembelian, karena desain sangat penting terutama pembuatan dan pemasaran jasa eceran, busana, barang kemasan, dan peralatan tahan lama. Desainer harus menemukan berapa banyak yang diinvestasikan dalam bentuk pengembangan fitur, kinerja, kesesuaian, ketahanan, keandalan, kemudahan perbaikan, dan gaya.

Hal tersebut dapat dibuktikan melalui penelitian yang telah dilakukan oleh Hamidah (2013), Achidah (2016) dan Asshididieqi (2012) menyatakan bahwa Desain berpengaruh positif dan signifikan terhadap keputusan pembelian

H2 = Adanya pengaruh positif dan signifikan antara Desain terhadap keputusan pembelian.

\section{Pengaruh harga $\left(\mathbf{X}_{3}\right)$ terhadap keputusan pembelian $(\mathbf{Y})$.}

Harga dapat diartikan sebagai jumlah uang (satuan moneter) dan atau aspek lain (non-moneter) yang mengandung kegunaan tertentu yang diperlukan untuk mendapatkan suatu produk (Hamidah, 2013). Harga adalah jumlah uang yang ditagihkan untuk suatu produk atau sejumlah nilai yang dipertukarkan konsumen untuk manfaat memiliki atau menggunakan produk.

Hal tersebut dapat dibuktikan melalui penelitian yang telah dilakukan oleh Basri (2016), Hamidah (2013), dan Achidah (2016) menyatakan bahwa persepsi harga berpengaruh positif dan signifikan terhadap keputusan pembelian

H3 = Adanya pengaruh positif dan signifikan antara Persepsi harga terhadap keputusan pembelian.

\section{Pengaruh antara kualitas produk $\left(X_{1}\right)$, desain produk $\left(X_{2}\right)$ dan harga produk $\left(X_{3}\right)$ terhadap keputusan pembelian (Y).}

Dari penjelasan diatas, tentang pengaruh kualitas produk, desain produk dan harga produk memberikan pengaruh positif terhadap keputusan pembelian. Semakin tinggi kualitas produk yang diberikan maka semakin tinggi pula keputusan pembelian pada Collection Furniture, dengan desain yang menarik dapat berpengaruh terhadapa keputusan pembelian, dan Jika harga memberikan tanggapan/ respon yang baik oleh konsumen, maka akan semakin tinggi pula pengambilan keputusan untuk membeli suatu produk di Collectian Furniture. 
H4 : Adanya pengaruh positif dan sihnifikan antara kualitas produk, desain produk dan harga produk terhadap keputusan pembelian.

\section{Kerangka Pemikiran}

Alasan variabel Kualitas Produk, Desain Produk, dan Harga Produk diteliti karena dari teori atau jurnal penelitian terdahulu menjelaskan tentang kualitas produk, desain produk dan harga produk untuk itu peneliti meneliti variabel tersebut guna mengetahui seberapa penting variabel tersebut berpengaruh terhadap keputusan pembelian yang dilakukan oleh pembeli mebel pada Collection Furniture dan juga dapat membantu perusahaan untuk meningkatkan mutu dari tiga variabel tersebut. Untuk lebih jelasnya dapat digambarkan dalam model sebagai berikut:

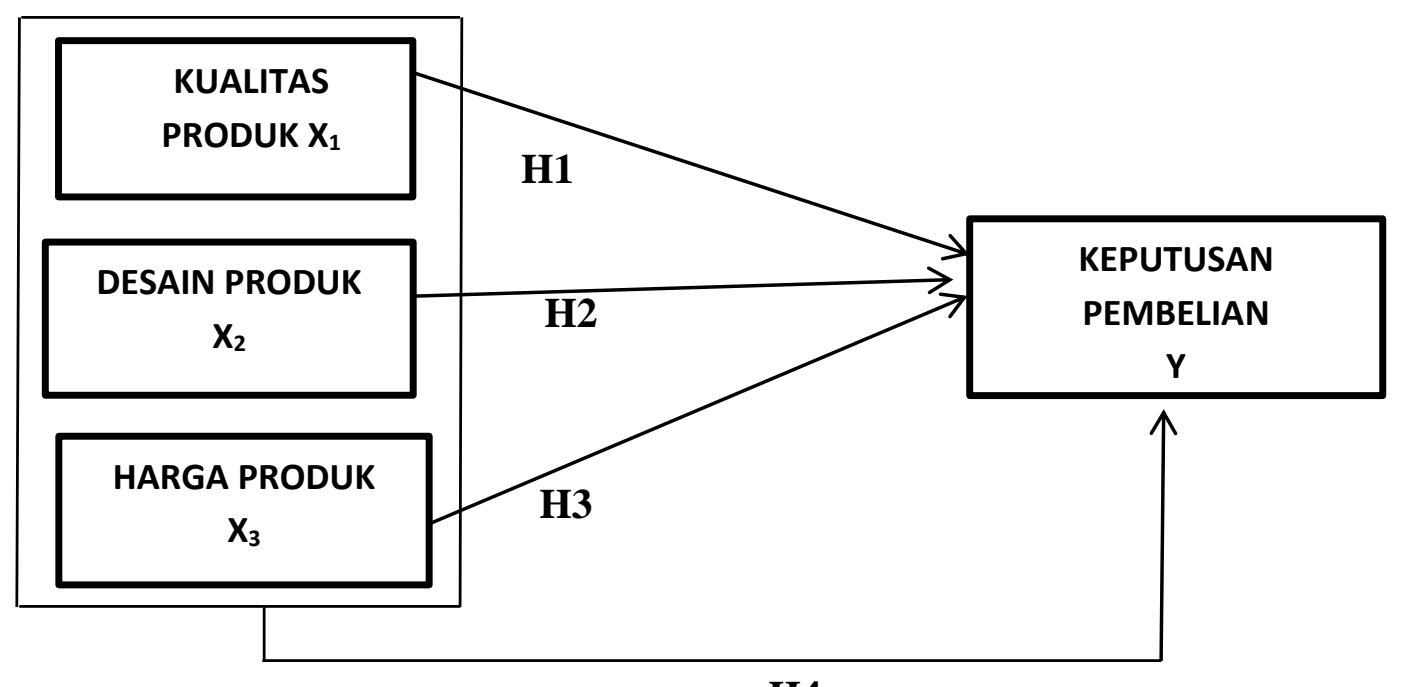

H4

\section{Gambar 1 \\ Kerangka Pemikiran}

Berdasarkan dari gambar diatas dapat dijelaskan :

H1 : Kualitas produk berpengaruh signifikan terhadap Keputusan pembelian

H2 : Desain produk berpengaruh terhadap Keputusan pembeian

H3 : Harga berpengaruh terhadap Keputusan pembelian

H4 : Kualitas produk, Desain produk dan Harga Produk berpengaruh terhadap Keputusan Pembelian.

\section{METODE PENELITIAN}

\section{Populasi dan Sampel}

Menurut Sugiyono (2015:148) populasi adalah wilayah generalisasi yang terdiri dari objek atau subjek yang mempunyai kualitas, kuantitas dan karakteristik tertentu yang ditetapkan oleh peneliti untuk dipelajari dan kemudian ditarik kesimpulannya. Populasi dalam penelitian ini adalah konsumen yang melakukan transaksi atau pembelian produk di Collection Furiture Pondo Bambu. Menurut Sugiyono (2015:149) Sampel adalah bagian dari jumlah dan karakteristik yang dimiliki oleh populasi tersebut. Sample dalam penelitian merupakan sebagian konsumen yang melakukan pembelian di Collection Furniture di Pondok Bambu. 
Karena jumlah popilasi tidak diketahui maka jumlah sampel dicari dengan rumus Isaac Michel :

$$
\mathrm{N}=1 / 4\left|\frac{Z \alpha / 2}{E}\right|^{2}
$$

Keterangan : $\mathrm{N}=$ Sample $\alpha=0,05$

$\mathrm{Z}=1,96$ (Nilai kurva normal simpangan)

$\mathrm{E}=$ Tinkat kesalahan dalam penelitian ini adalah $15 \%$

Sehingga yang dihasilkan :

$$
\mathrm{N}=1 / 4\left|\frac{1,96}{0,15}\right|^{2}=1 / 4|19,6|^{2}=1 / 4|384,16| \quad \mathrm{N}=96,04
$$

Atas dasar perhitungan diatas maka sample diambil adalah berjumlah 96 orang, dibulatkan menjadi 96,4 dibulatkan menjadi 96 konsumen.

\section{Metode Analisis Data}

Metode analisa data yang akan dipergunakan oleh peneliti adalah menggunakan analisis deskriptif. Menurut Abdul Hakim (2010:8) statistik deskriptif adalah ilmu yang berisi metode-metode pengumpulan, penyajian, dan pengaturan data guna membuat gambaran yang jelas tentang variasi sifat data, yang pada akhirnya akan mempermudah proses analisis dan interpretasi data. Untuk menguji pengaruh Kualitas produk $\left(\mathrm{X}_{1}\right)$, Desain produk $\left(\mathrm{X}_{2}\right)$ dan Harga $(\mathrm{X} 3)$ dengan Keputusan pembelian (Y) secara bersamaan. Metode penelitian yang digunakan dalam penelitian ini menggunakan penelitian deskriptif karena dalam penelitian ini akan dijelaskan mengenai pengaruh kualitas produk, desain produk, dan harga produk terhadap keputusan pembelian Collection furniture.

\section{HASIL PENELITIAN DAN PEMBAHASAN Hasil Uji Validitas}

Uji validitas digunakan untuk melihat valid atau tidaknya suatu kuisioner sebagai alat ukur variabel, dalam mengukur valid atau tidaknya suatu kuisioner dilakukan dengan melakukan korelasi hasil jawaban responden pada masing-masing pertanyaan di setiap variabel, dimana analisanya menggunakan program SPSS versi 22, dengan output corrected item correlation ( Ghozali,2009) hasil $\mathrm{r}$ hitung ini kemudian dibandingkan dengan $r$ tabel product moment, dimana dengan $n=30$ dan $\alpha=0,05$ maka didapat $r$ tabel dua sisi sebesar 0,165 dengan ketentuan Hasil $r$ hitung $>r$ tabel $(0,361)=$ valid Hasil $r$ hitung $<\mathrm{r}$ tabel $(0,361)=$ tidak valid Hasil uji validitas dari setiap pertanyaan kuisioner yang digunakan pada variabel kualitas produk, desain produk dan harga produk.

\section{Hasil Uji Reliabilitas}

Uji reliabilitas dilakukan untuk mengetahui kehandalan dari suatu alat ukur (kuesioner) dalam mengukur suatu variabel (Ghozali,2009). Pengukuran reliabilitas dapat dilakukan dengan One Shot atau pengukuran sekali saja. Disini pengukurannya hanya sekali dan kemudian hasilnya dibandingkan dengan pertanyaan lain atau mengukur korelasi antar jawaban pertanyaan. Alat untuk mengukur reliabilitas adalah Cronbach Alpha. Suatu variabel dikatakan reliabel, apabila : Hasil $\alpha>0,60=$ reliabel.

\section{Uji Normalitas} atau tidak.

Pengujian ini dilakukan untuk menguji apakah nilai residual terdistribusi normal 


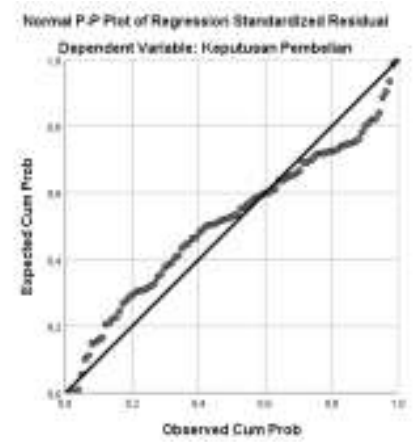

Gambar 2

\section{Hasil Uji Normalitas Probability Plot}

Berdasarkan pada gambar 4.1 dapat dilihat bahwa titik-titik menyebar disekitar garis diagonal dna penyebarannya mengikuti arah garis diagonal, maka dapat dinyatakan data memenuhi asumsi normalitas.

\section{Uji Multikolinieritas}

Uji multikolinearitas adalah untuk melihat ada atau tidaknya kolerasi yang tinggi antara variabel-variabel bebas dalam satu model regresi linier berganda.

\section{Tabel 2}

\section{Hasil Uji Multikolinieritas Tolerance dan VIF}

\begin{tabular}{|c|c|c|c|c|c|c|c|c|}
\hline \multicolumn{9}{|c|}{ Coefficients $^{a}$} \\
\hline & & \multicolumn{2}{|c|}{$\begin{array}{c}\text { Unstandardized } \\
\text { Coefficients }\end{array}$} & \multirow{2}{*}{$\begin{array}{c}\begin{array}{c}\text { Standar } \\
\text { dized } \\
\text { Coeffici } \\
\text { ents }\end{array} \\
\text { Beta }\end{array}$} & \multirow[b]{2}{*}{$\mathrm{T}$} & \multirow[b]{2}{*}{ Sig. } & \multicolumn{2}{|c|}{$\begin{array}{l}\text { Collinearity } \\
\text { Statistics }\end{array}$} \\
\hline \multicolumn{2}{|c|}{ Model } & B & $\begin{array}{l}\text { Std. } \\
\text { Error }\end{array}$ & & & & $\begin{array}{l}\text { Toler } \\
\text { ance }\end{array}$ & VIF \\
\hline 1 & $\begin{array}{l}\text { (Consta } \\
\text { nt) }\end{array}$ & $-5,408$ & 2,635 & & $\begin{array}{r}- \\
2,05 \\
2\end{array}$ & ,043 & & \\
\hline & $\begin{array}{l}\text { Kualitas } \\
\text { Produk }\end{array}$ &, 577 & ,083 & ,521 & $\begin{array}{r}6,91 \\
1\end{array}$ & ,000 & ,366 & $\begin{array}{r}2,73 \\
2\end{array}$ \\
\hline & $\begin{array}{l}\text { Desain } \\
\text { Produk }\end{array}$ & ,499 & ,051 & ,511 & $\begin{array}{r}9,74 \\
5\end{array}$ & 000 & ,756 & $\begin{array}{r}1,32 \\
3\end{array}$ \\
\hline & $\begin{array}{l}\text { Harga } \\
\text { Produk }\end{array}$ & ,016 & ,090 & ,012 & , 177 & ,860 & , 427 & $\begin{array}{r}2,34 \\
1\end{array}$ \\
\hline
\end{tabular}

a. Dependent Variable: Keputusan Pembelian

Pada lampiran tabel Coefficients, nilai Variance Inflation Factor (VIF) dari semua variabel bebas memiliki nilai yang lebih kecil dari 10 dan nilai tolerance diatas 0,1 yaitu untuk VIF kualitas produk 2.732, desain produk 1,323, dan harga produk 2.341 terhadap keputusan pembelian dan nilai tolerance Kualitas Produk 0,366, Desain Produk 0,756 dan Harga Produk 0,427. Hal ini bahwa variabel - variabel penelitian tidak terjadi multikolinieritas dalam model regresi.

\section{Uji Heteroskedastisitas}

Uji heteroskesdastisitas dilakukan untuk menguji kelompok dan penelitian, apakah memiliki varian yang sama atau tidak. 


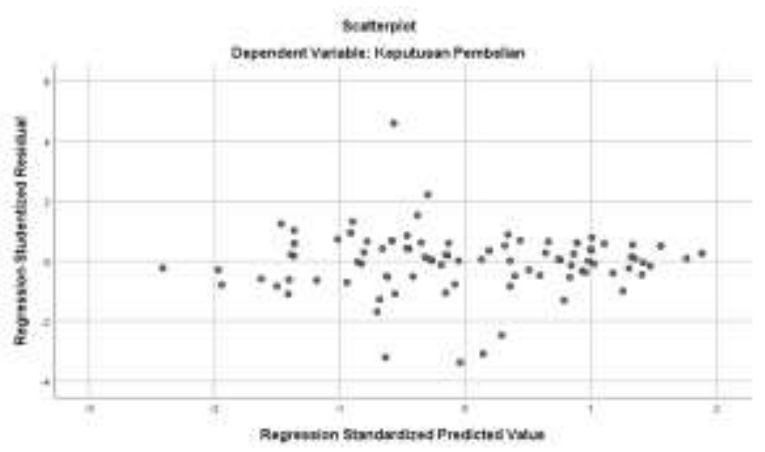

Gambar 3

Uji heteroskedastisitas scatterplot

Berdasarkan gambar 4.2 maka dapat dilihat bahwa titik-titik tersebar diatas dan dibawah angka 0 pada sumbu Y, maka dapat disimpulkan bahwa tidak terjadi heteroskedastisitas. Dengan kata lain terdapat kesamaan varian dari residual pada penelitian ini.

\section{Analisis Regresi Sederhana antara X1 dan Y}

Analisis yang digunakan untuk memprediksi seberapa jauh perubahan nilai variabel depeden, bila nilai variabel independen dimanipulasi atau dinaik turunkan. Untuk menguji $\mathrm{H}_{1}$ : Kualitas Poduk memiliki pengaruh yang signifikan terhadap Keputusan Pembelian, menggunakan rumus $\mathrm{Y}=\mathrm{a}+\mathrm{B}$.

Tabel 3

Hasil Analisis Regresi Sederhana $X_{1}$ dan Y

\begin{tabular}{|c|c|c|c|c|c|c|}
\hline \multicolumn{7}{|c|}{ Coefficients $^{a}$} \\
\hline & \multirow[b]{2}{*}{ Model } & \multicolumn{2}{|c|}{$\begin{array}{c}\text { Unstandardized } \\
\text { Coefficients }\end{array}$} & $\begin{array}{c}\text { Standardized } \\
\text { Coefficients }\end{array}$ & \multirow[b]{2}{*}{$\mathrm{T}$} & \multirow[b]{2}{*}{ Sig. } \\
\hline & & $\mathrm{B}$ & Std. Error & Beta & & \\
\hline \multirow[t]{2}{*}{1} & (Constant) & 24.300 & 3.856 & & 6.302 & .000 \\
\hline & $\begin{array}{l}\text { Kualitas } \\
\text { Produk }\end{array}$ & .372 & .100 & .360 & 3.736 & .000 \\
\hline
\end{tabular}

a. Dependent Variable: Keputusan Pembelian

Berdasarkan tabel 4.16 analisis regresi sederhana antara $\mathrm{X}_{1}$ dan $\mathrm{Y}$ didapatkan persamaan regresi: $\mathrm{Y}=24,300+0,372 \mathrm{X}_{1}$. Dari persamaan diatas dapat dijelaskan sebagai berikut :

Nilai $\mathrm{a}=24,300$ yaitu bahwa jika tidak ada perubahan dari variabel Kualitas Produk, maka nilai skor Keputusan Pembelian adalah 24,300

Nilai $b=0,372$ artinya setiap penambahan satu skor nilai pada Kualitas Produk, maka Keputusan Pembelian akan mengalami peningkatan skor sebesar 0,372 kali. 


\section{Analisis Regresi Sederhana antara X2 dan Y}

Untuk menguji H2 : Desain Produk memiliki pengaruh yang signifikan terhadap Keputusan Pembelian, menggunakan rumus $\mathrm{Y}={ }_{\mathrm{a}+\mathrm{b} 1} \mathrm{X}_{2}$ :

Tabel 4

Hasil Analisis Regresi Sederhana $X_{2}$ dan $Y$ Coefficients $^{a}$

\begin{tabular}{|c|c|c|c|c|c|}
\hline \multirow[b]{2}{*}{ Model } & \multicolumn{2}{|c|}{$\begin{array}{l}\text { Unstandardized } \\
\text { Coefficients }\end{array}$} & \multirow{2}{*}{$\begin{array}{c}\text { Standardiz } \\
\text { ed } \\
\text { Coefficient } \\
\text { s }\end{array}$} & \multirow[b]{2}{*}{$\mathrm{t}$} & \multirow[b]{2}{*}{ Sig. } \\
\hline & $B$ & Std. Error & & & \\
\hline $\begin{array}{ll}1 & \text { (Consta } \\
\text { nt) }\end{array}$ & 25.362 & 3.526 & & 7.194 & .000 \\
\hline Desain & .332 & .088 & .364 & 3.789 & .000 \\
\hline
\end{tabular}

a. Dependent Variable: Keputusan Pembelian

Berdasarkan tabel 4.17 analisis regresi sederhana antara $\mathrm{X}_{2}$ dan $\mathrm{Y}$ didapatkan persamaan regresi: $\mathrm{Y}=25,362+0,332 \mathrm{X}_{2}$. Dari persamaan diatas dapat dijelaskan sebagai berikut :

Nilai $\mathrm{a}=25,362$ yaitu bahwa jika tidak ada perubahan dari variabel Desain Produk, maka nilai skor Keputusan Pembeliana dalah 25,362

Nilai $b=0,332$ artinya setiap penambahan satu skor nilai pada Desain Produk, maka Keputusan Pembelian akan mengalami peningkatan skor sebesar 0,332 kali

\section{Analisis Regresi Sederhana antara X3 dan Y}

Untuk menguji H3 : Harga Produk memiliki pengaruh yang signifikan terhadap Keputusan Pembelian, menggunakan rumus $\mathrm{Y}={ }_{\mathrm{a}+\mathrm{b} 1} \mathrm{X}_{2}$ :

\section{Tabel 5}

\section{Hasil Analisis Regresi Sederhana $X_{3}$ dan Y}

\begin{tabular}{|c|c|c|c|c|c|c|}
\hline \multicolumn{7}{|c|}{ Coefficients $^{a}$} \\
\hline & & \multicolumn{2}{|c|}{$\begin{array}{c}\text { Unstandardized } \\
\text { Coefficients }\end{array}$} & $\begin{array}{c}\text { Standardize } \\
d \\
\text { Coefficients }\end{array}$ & & \\
\hline \multicolumn{2}{|c|}{ Model } & $B$ & Std. Error & Beta & $\mathrm{t}$ & Sig. \\
\hline \multirow[t]{2}{*}{1} & (Constant) & 6,657 & 4,462 & & 1,492 & ,139 \\
\hline & $\begin{array}{l}\text { Harga } \\
\text { Produk }\end{array}$ & ,747 & , 108 & ,579 & 6,891 &, 000 \\
\hline
\end{tabular}

a. Dependent Variable: Keputusan Pembelian

Berdasarkan tabel 4.18 analisis regresi sederhana antara $\mathrm{X}_{3}$ dan $\mathrm{Y}$ didapatkan persamaan regresi: $\mathrm{Y}=6,657+0,747 \mathrm{X}_{3}$. Dari persamaan diatas dapat dijelaskan sebagai berikut:

Nilai $\mathrm{a}=$ 6,657 yaitu bahwa jika tidak ada perubahan dari variabel Harga Produk, maka nilai skor Keputusan Pembeliana dalah 6,657 
Nilai $b=0,747$ artinya setiap penambahan satu skor nilai pada harga Produk, maka Keputusan Pembelian akan mengalami peningkatan skor sebesar 0,747 kali

\section{Analisis Regresi Berganda antara X1, X2, X3 dan Y}

Adalah analisis yang digunakan untuk meramalkan bagaimana keadaan (naik turunnya) variabel dependen, bila dua atau lebih variabel independen dimanipulasi atau dinaik turunkan. Jadi analisis regresi akan dilakukan bila jumlah variabelnya dependen minimal.

Tabel 6

Hasil Analisis Regresi Berganda $X_{1}, X_{2}, X_{3}$ dan $Y$

Coefficients $^{a}$

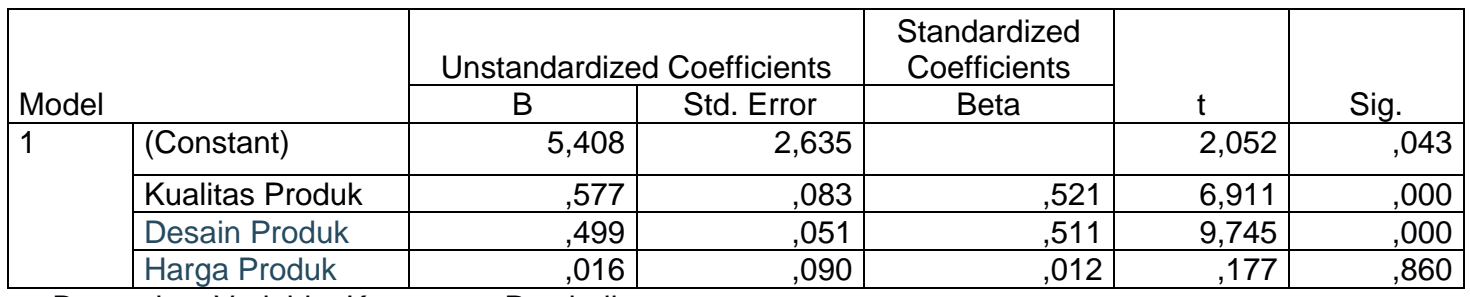

a. Dependent Variable: Keputusan Pembelian

Uji korelasi bertujuan untuk mengetahui tingkat keeratan hubungan antar variabel yang dinyatakan dengan koefisien korelasi.

\section{Analisis Korelasi Sederhana X1 dan Y}

Digunakan untuk mengetahui kuatnya hubungan variabel X1 dan Y, X2 dan Y dan Variabel X3 dan Y, jenis hubungan antar variabel X dan Y dapat bersifat positif dan negative. Cara perhitungan ini dapat menggunakan rumus dalam sujarweni (2015:108), sebagai berikut :

\section{Tabel 7}

Hasil Analisis Korelasi Sederhana X1 dan Y

Correlations

\begin{tabular}{|c|c|c|c|}
\hline & & Kualitas Produk & $\begin{array}{l}\text { Keputusan } \\
\text { Pembelian }\end{array}$ \\
\hline \multirow[t]{3}{*}{ Kualitas Produk } & Pearson Correlation & $\overline{1}$ & $.360^{* *}$ \\
\hline & Sig. (2-tailed) & & .000 \\
\hline & $\mathrm{N}$ & 96 & 96 \\
\hline \multirow[t]{3}{*}{ Keputusan Pembelian } & Pearson Correlation & $.360^{* *}$ & $\overline{1}$ \\
\hline & Sig. (2-tailed) & .000 & \\
\hline & $\mathrm{N}$ & 96 & 96 \\
\hline
\end{tabular}

${ }^{\star *}$. Correlation is significant at the 0.01 level (2-tailed).

Berdasarkan tabel 4.20 diketahui nilai $r=0,360$, maka terdapat hubungan keeratan yang rendah dan positif antara Kualitas Produk (X1) dan Keputusan Pembelian (Y). 


\section{Analisis Korelasi Sederhana X2 dan Y}

\section{Tabel 8}

Hasil Analisis Korelasi Sederhana X2 dan Y

Correlations

\begin{tabular}{|l|l|r|r|}
\hline \multicolumn{2}{|c|}{} & \multicolumn{1}{|c|}{$\begin{array}{c}\text { Keputusan } \\
\text { Pembelian }\end{array}$} \\
\hline \multirow{3}{*}{ Desain } & Pearson Correlation & 1 & $.364^{* *}$ \\
\cline { 2 - 4 } & Sig. (2-tailed) & & .000 \\
\cline { 2 - 4 } & $\mathrm{N}$ & 96 & 96 \\
\hline \multirow{3}{*}{ Keputusan Pembelian } & Pearson Correlation & $.364^{* *}$ & 1 \\
\cline { 2 - 4 } & Sig. (2-tailed) & .000 & 96 \\
\cline { 2 - 4 } & $\mathrm{N}$ & 96 & \\
& \multirow{2}{*}{. Correlation is significant at the 0.01 level (2-tailed). }
\end{tabular}

Berdasarkan tabel 4.21 diketahui nilai $\mathrm{r}=0,364$, maka terdapat hubungan keeratan yang rendah dan positif antara Desain Produk (X2) dan Keputusan Pembelian (Y).

\section{Analisis Korelasi Sederhana X3 dan Y}

Tabel 9

Hasil Analisis Korelasi Sederhana X3 dan Y Correlations

\begin{tabular}{|l|l|r|r|}
\hline \multicolumn{2}{|c|}{} & Harga Produk & $\begin{array}{r}\text { Keputusan } \\
\text { Pembelian }\end{array}$ \\
\hline \multirow{3}{*}{ Harga Produk } & Pearson Correlation & 1 &, $579^{* *}$ \\
\cline { 2 - 4 } & Sig. (2-tailed) & &, 000 \\
\cline { 2 - 4 } & $\mathrm{N}$ & 96 & 96 \\
\hline Keputusan Pembelian & Pearson Correlation &, $579^{* *}$ & 1 \\
\cline { 2 - 4 } & Sig. (2-tailed) &, 000 & 96 \\
\cline { 2 - 4 } & $\mathrm{N}$ & 96 & \\
\hline \multirow{2}{*}{. Correlation is significant at the 0.01 level (2-tailed). }
\end{tabular}

Berdasarkan tabel 4.22 diketahui nilai $r=0,579$, maka terdapat hubungan keeratan yang sedang dan positif antara Harga Produk (X3) dan Keputusan Pembelian (Y).

\section{Analisis Korelasi Berganda}

Adanya angka yang menunjukan arah dan kuatnya hubungan antara dua variabel independen secara bersama-sama atau lebih dengan satu variabel dependen. Sebagaimana yang dinyatakan oleh sugiyono (2016:191) dengan rumus sebagai berikut :

\section{Tabel 10}

\section{Hasil Analisis Korelasi Berganda $X_{1}, X_{2} X_{3}$ dan $Y$}

Model Summary

\begin{tabular}{|c|c|c|c|c|c|c|c|c|c|}
\hline \multirow[b]{2}{*}{$\begin{array}{l}\text { Mod } \\
\text { el }\end{array}$} & \multirow[b]{2}{*}{$\mathrm{R}$} & \multirow[b]{2}{*}{$\begin{array}{c}\mathrm{R} \\
\text { Square }\end{array}$} & \multirow[b]{2}{*}{$\begin{array}{l}\text { Adjusted R } \\
\text { Square }\end{array}$} & \multirow{2}{*}{$\begin{array}{l}\text { Std. Error } \\
\text { of the } \\
\text { Estimate }\end{array}$} & \multicolumn{5}{|c|}{ Change Statistics } \\
\hline & & & & & $\begin{array}{l}\text { R Square } \\
\text { Change }\end{array}$ & $\begin{array}{c}\mathrm{F} \\
\text { Change }\end{array}$ & $\mathrm{df1}$ & $\mathrm{df} 2$ & $\begin{array}{c}\text { Sig. F } \\
\text { Change }\end{array}$ \\
\hline 1 &, $899^{a}$ & ,809 & ,802 & 2,40107 & ,809 & 129,608 & 3 & 92 &, 000 \\
\hline
\end{tabular}

a. Predictors: (Constant), Harga Produk, Desain Produk, Kualitas Produk 
Berdasarkan tabel 4.23 diketahui nilai $\mathrm{r}=0,899$, maka terdapat hubungan keeratan yang kuat dan positif antara Kualitas Produk (X1), Desain Produk (X2) dan Harga Produk (X3) dan Keputusan Pembelian (Y)..

\section{Analisis Koefisien Determinasi}

Uji Koefisien Determinasi digunakan untuk mengetahui seberapa besar pengaruh kontribusi variabel Kualitas Produk (X1), Desain Produk (X2), dan Harga Produk (X3) terhadap Keputusan Pembelian.

Tabel 11

Hasil Analisis Koefisien Determinasi

\begin{tabular}{|c|c|c|c|c|}
\hline \multicolumn{5}{|c|}{ Model Summary } \\
\hline Model & $\mathrm{R}$ & R Square & $\begin{array}{l}\text { Adjusted R } \\
\text { Square }\end{array}$ & $\begin{array}{l}\text { Std. Error of the } \\
\text { Estimate }\end{array}$ \\
\hline 1 &, $899^{a}$ & ,809 & ,802 & 2,40107 \\
\hline
\end{tabular}

Berdasarkan tabel 4.24 diatas dapat disajikan interprestasi atau arti ekonominya sebagai berikut :

a. R menunjukan korelasi berganda, yaitu korelasi antara dua atau lebih variabel independen terhadap variabel dependen. Angka $\mathrm{R}$ yang didapat yaitu 0,899 artinya korelasi antara kedua variabel $\mathrm{X}$ terhadap $\mathrm{Y}$ sebesar 0,899 Hal ini berarti hubungan yang kuat karena nilai mendekati 1 .

b. R square (R2) atau R kuadrat menunjukkan koefisien determinasi. Nilai R2 sebesar 0,809 artinya presentase sumbangan pengaruh variabel $\mathrm{X}$ terhadap $\mathrm{Y}$ sebesar $80,9 \%$ sedangkan sisanya sebesar $19,1 \%$ dipengaruhi oleh variabel lain yang tidak dimasukkan dalam model ini.

\section{Uji Hipotesa}

\section{Uji t (Uji Parsial)}

Uji t bertujuan untuk mengetahui sigifikasi antara variabel independen secara parsial dengan variabel dependen.

Berdasarkan dengan perhitungan SPSS 22, maka diperoleh hasil sebagai berikut :

Tabel 12

Hasil Uji t

Coefficients $^{\mathrm{a}}$

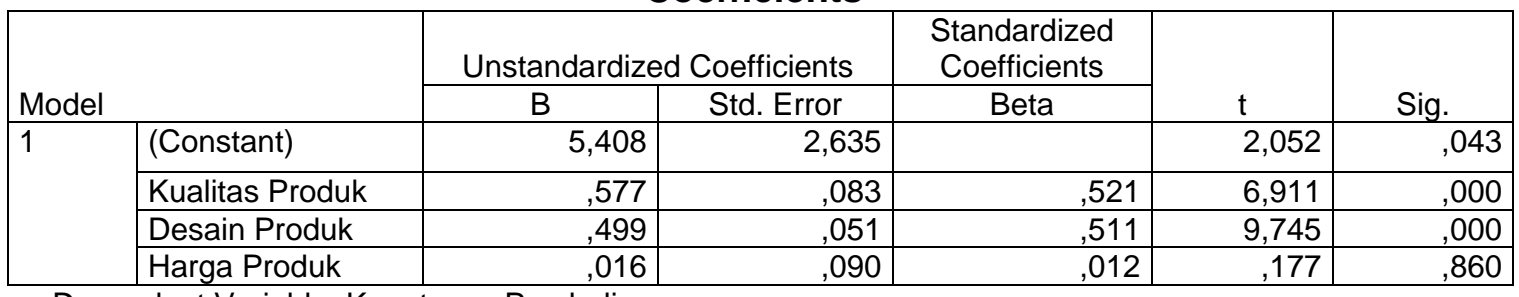

a. Dependent Variable: Keputusan Pembelian 


\section{Uji f (Uji Simultan)}

Uji f dilakukan untuk menguji ada tidaknya pengaruh variabel-variabel independen terhadap variabel dependen secara simultan (bersama-sama). Berdasarkan pengujian yang dilakukan diperoleh hasil sebagai berikut:

\section{Tabel 13}

\section{Hasil Uji f}

\section{ANOVA $^{\mathrm{a}}$}

\begin{tabular}{|l|l|r|r|r|r|r|}
\hline \multicolumn{2}{|l|}{ Model } & Sum of Squares & Df & Mean Square & F & Sig. \\
\hline \multirow{3}{*}{1} & Regression & 2241,609 & 3 & 747,203 & 129,608 &, $000^{\mathrm{b}}$ \\
\cline { 2 - 8 } & Residual & 530,391 & 92 & 5,765 & & \\
\cline { 2 - 8 } & Total & 2772,000 & 95 & & & \\
\hline
\end{tabular}

a. Dependent Variable: Keputusan Pembelian

b. Predictors: (Constant), Harga Produk, Desain Produk, Kualitas Produk

Berdasarkan tabel 4.26 maka diperoleh taraf signifikan sebesar 0,000 dan $f_{\text {hitung }}$ 129,608 yang menunjukkkan bahwa tingkat signifikan $0,000<0,05$ dan $\mathrm{f}_{\text {hitung }} 129,608>$ $\mathrm{f}_{\text {tabel }}$ 3,09, maka dapat disimpulkan bahwa Ha diterima, artinya bahwa Kualitas produk, Desain Produk dan Harga Produk secara bersama-sama berpengaruh signifikan terhadap Keputusan Pembelian.

\section{Pembahasan}

Berdasarkan dari analisa dengan program IBM SPSS versi 26 maka diperoleh hasil-hasil sebagai berikut :

\section{Pengaruh Kualitas Produk terhadap keputusan pembelian}

Hasil penelitian ini menunjukkan bahwa kualitas produk berpengaruh positif dan signifikan terhadap keputusan pembelian. Dari hasil uji t sebesar 6,911 dan sig 0,000< $\alpha$ 0,05 kualitas produk signifikan terhadap keputusan pembelian. Sehingga hipotesis yang menyatakan bahwa kualitas produk berpengaruh positif dan signifikan terhadap keputusan pembelian terbukti kebenarannya. Adanya nilai positif dan signifikan ini dapat diartikan jika kualitas produk dengan kinerja, daya tarik atau corak produk, penampilan, dan produk tidak muda cacat diberikan sesuai dengan harapan yang diinginkan konsumen, maka mampu meningkatkan keputusan pembelian terhadap mebel Collection Furniture.

\section{Pengaruh Desain Produk Terhadap Keputusan Pembelian}

Hasil penelitian ini menunjukkan bahwa desain produk berpengaruh positif dan signifikan terhadap keputusan pembelian. Dari hasil uji t sebesar 9,745 dan sig 0,00 $<\alpha 0,05$. Adanya nilai positif dan signifikan ini dapat diartikan desain dari beberapa indikator model, gaya yang menarik, variasi, up to date atau mengikuti perkembangan zaman. Jika dari beberapa indikator dari desain Collection Furniture mampu menciptakan variasi model baru setiap tahunnya maka akan meningkatkan keputusan pembelian terhadap Collection Furniture. Desain produk berpengaruh signifikan terhadap Keputusan Pembelian. Sehingga hipotesis yang menyatakan bahwa Keputusan Pembelian berpengaruh positif dan signifikan terhadap Keputusan Pembelian terbukti kebenarannya, jadi $\mathrm{H} 2$ diterima.

\section{Pengaruh Harga Produk Terhadap Keputusan Pembelian}

Dengan taraf signifikansi Harga Produk uji t sebesar 0,177 dan sig 0,860> $\alpha$ 0,05. Bahwa Harga Produk tidak berpengaruh signifikan terhadap Keputusan Pembelian. Sehingga hipotesis yang menyatakan bahwa Harga Produk tidak berpengaruh positif dan tidak signifikan terhadap Keputusan Pembelian, jadi H3 ditolak. 


\section{Pengaruh Kualitas Produk, Desain Produk dan Harga Produk terhadap Keputusan Pembelian}

Berdasarkan hasil analisa data dan pengujian hipotesis dalam penelitian ini menunjukkan bahwa secara simultan variabel Kualitas Produk (X1), Desain Produk (X2), Harga Produk (X3) secara bersama-sama berpengaruh positif dan signifikan terhadap Keputusan Pembelian (Y). Nilai fhitung sebesar 129,603 sedangkan ftabel sebesar 3,09 dengan df pembilang $=3$, df penyebut $=92$ dan taraf signifikan $=0,05$, sehingga fhitung lebih besar dari ftabel dan nilai signifikansinya sebesar 0,000 yang mana nilai tersebut lebih kecil dari 0,05. Berdasarkan kedua nilai tersebut maka dapat dinyatakan H4 diterima, dimana Kualitas Produk, Desain Produk dan Harga Produk berpengaruh positif dan signifikan terhadap Keputusan Pembelian. Dengan demikian perusahaan Collection Furniture harus memperhatikan dan meningkatkan terutama dalam Kualitas Produk. Desain Produk dan Harga Produk untuk meningkatkan penjualan Collection Furniture.

\section{KESIMPULAN}

\section{Berdasarkan Hasil Regresi}

a. Regresi Sederhana X1 dan Y

Hasil penelitian ini menunjukan nilai thitung 3.736 lebih besar dari tabel 1.9860 dengan nilai signifikan 0.000 lebih kecil dari 0,05, dengan demikian dapat disimpulkan bahwa $\mathrm{H}_{1}$ yang menyatakan variabel Kualitas Produk berpengaruh positif dan signifikan terhadap Keputusan Pembelian.

b. Regresi Sederhana X2 dan Y

Hasil penelitian ini menunjukan nilai $t_{\text {hitung }} 3.789$ lebih besar dari $t_{\text {tabel }} 1.9860$ dengan nilai signifikan 0,000 lebih kecil dari 0,05, dengan demikian dapat disimpulkan bahwa $\mathrm{H}_{2}$ yang menyatakan variabel Desain Produk berpengaruh positif dan signifikan terhadap Keputusan Pembelian.

c. Regresi Sederhana X3 dan Y

Hasil penelitian ini menunjukan nilai $t_{\text {hitung }} 6.891$ lebih besar dari $t_{\text {tabel }} 1.9860$ dengan nilai signifikan 0,000 lebih kecil dari 0,05, dengan demikian dapat disimpulkan bahwa $\mathrm{H}_{3}$ yang menyatakan variabel Harga Produk berpengaruh positif dan signifikan terhadap Keputusan Pembelian.

d. Regresi Berganda X1,X2 dan Y

Hasil penelitian ini menunjukan dengan nilai signifikan 0,043 lebih kecil dari 0,05, dengan demikian dapat disimpulkan bahwa $\mathrm{H}_{1}, \mathrm{H}_{2}$ dan $\mathrm{H}_{3}$ yang menyatakan variabel Kualitas Produk, Desain Produk dan Harga Produk bersama-sama berpengaruh positif dan signifikan terhadap Keputusan Pembelian.

\section{Berdasarkan Hasil Korelasi}

a. Korelasi Sederhana X1 dan Y

Besaran Kualitas Produk dan Keputusan Pembelian, nilai koefisien korelasinya ialah 0,360, hal ini juga menunjukan bahwa adanya korelasi yang rendah dan positif.

b. Korelasi Sederhana X2 dan Y

Besaran Desain Produk dan Keputusan Pembelian, nilai koefisien korelasinya ialah 0,364, hal ini juga menunjukan bahwa adanya korelasi yang rendah dan positif.

c. Korelasi Sederhana X3 dan Y

Besaran Harga Produk dan Keputusan Pembelian, nilai koefisien korelasinya ialah 0,579, hal ini juga menunjukan bahwa adanya korelasi yang sedang dan positif d. Korelasi Berganda X1,X2,X3 dan Y 
Besarnya hubungan antara Celebrity Endorser dan Brand Image adalah sebesar 0,899 . Hal ini menunjukan pengaruh yang rendah dan positif.

\section{Berdasarkan koefisien Determinasi}

Koefisien determinasi $\mathrm{R}$ squer $=0,809$ artinya presentase sumbangan pengaruh variabel X terhadap Y sebesar $80.9 \%$ sedangkan sisanya sebesar $19.1 \%$ dipengaruhi oleh variabel lain yang tidak dibahas dalam penelitian ini.

\section{Berdasarkan Uji T dan Uji F}

a. Kualitas Produk

Berdasarkan taraf signifikan Kualitas Produk sebesar 0.00 dan thitung sebesar 6,911 menunjukkan bahwa tingkat signifikansi $0,00<0,05$ dan $t_{\text {hitung }} 6,911<t_{\text {tabel }}$ 1.9860. Kesimpulan: variabel Kualitas Produk $\left(\mathrm{H}_{1}\right)$ berpengaruh dan signifikan terhadap Keputusan Pembelian.

a. Desain Produk

Berdasarkan taraf signifikan Desains Produk sebesar 0.00 dan $t_{\text {hitung }}$ sebesar 9.745 menunjukkan bahwa tingkat signifikansi $0,00<0,05$ dan $t_{\text {hitung }} 9.745<\mathrm{t}_{\text {tabel }}$ 1.9860. Kesimpulan: variabel Desain Produk $\left(\mathrm{H}_{2}\right)$ berpengaruh dan signifikan terhadap Keputusan Pembelian

c. Harga Produk

Berdasarkan taraf signifikan Harga Produk sebesar 0.860 dan thitung sebesar 0.177 menunjukkan bahwa tingkat signifikansi $0,860>0,05$ dan $t_{\text {hitung }} 0.177<t_{\text {tabel }}$ 1.9860. Kesimpulan: variabel Harga Produk $\left(\mathrm{H}_{3}\right)$ tidak berpengaruh signifikan terhadap Keputusan Pembelian.

d. Uji F (simultan)

Berdasarkan taraf signifikan sebesar 0,000 dan $\mathrm{f}_{\text {hitung }}$ 129,608 menunjukkkan bahwa tingkat signifikan $0,000<0,05$ dan $\mathrm{f}_{\text {hitung }} 129,608>\mathrm{f}_{\text {tabel }} 3,09$, artinya bahwa Kualitas Produk, Desain Produk dan Harga Produk secara bersama-sama berpengaruh signifikan terhadap Keputusan Pembelian.

\section{Saran - saran}

Berdasarkan kesimpulan yang diperoleh dalam penelitian ini, maka diajukan saran-saran sebagai berikut :

1. Kualitas produk merupakan variabel pertama yang memiliki pengaruh terhadap keputusan pembelian mebel Collection Furniture. berdasarkan hasil jawaban responden diketahui bahwa indikator variabel terendah yaitu terdapat pada indikator kualitas produk mengenai motif dan warnanya. Hal ini berarti bahwa produk MS Furniture Vintage mendapatkan respon baik mengenai memiliki kualitas tahan lama oleh konsumen. Kualitas produk dan kinerja yang baik dari Collection Furniture memberikan keputusan pembelian menjadi semakin tinggi.

2. Desain merupakan variabel kedua yang memiliki pengaruh tertinggi terhadap keputusan pembelian Collection Furniture. Kelemahan dari desain Collection Furniture yaitu berdasarkan hasil jawaban responden mengenai kuesioner diketahui bahwa indikator variabel yang terendah yaitu terdapat pada indikator Model, untuk itu sebaiknya Collection Furniture mampu meningkatkan gaya yang inovatif yang mampu menarik minat konsumen pembeli Collection Furniture. Sedangkan nilai rata-rata tertinggi pada indikator mengenai desain yang selalu Up to date atau mengikuti perkembangan jaman. Collection Furniture sudah mampu memberikan respon baik terhadap desain yang selalu mengikuti trend hal ini mampu meningkatkan keputusan pembelian pada Collection Furniture. 
3. Harga Produk merupakan variabel ketiga yang memiliki pengaruh terendah terhadap keputusan pembelian Collection Furniture. Kelemahan dari produk Collection Furniture yaitu berdasarkan hasil jawaban responden diketahui bahwa indikator rata-rata terendah pada indikator mengenai keterjangkaun harga. Untuk itu sebaiknya pihak Collection Furniture lebih mengutamakan kesepakatan antara pihak perusahaan dan konsumen untuk membicarakan harga yang disepakati kedua pihak supaya dapat sebanding dengan apa yang diinginkan konsumen. hal ini bertujuan untuk meningkatkan keputusan pembelian Collection Furniture.

4. Untuk meningkatkan Keputusan Pembelian berdasarkan hasil jawaban responden diketahui bahwa pernyataan terendah pada pembelian pada mebel Collection Furniture karena mempunyai produk - prdouk baru. Untuk itu sebaiknya mebel Collection Furniture untuk selalu mengeluarkan inovasi baru pada kualitas produk, desain untuk produk - produk barunya, sehingga dapat meningkatkan keputusan pembelian. Sedangkan nilai rata-rata tertinggi pada pernyataan tertinggi yaitu Mebel Collection Furniture memiliki kinerja yang baik dalam menghasilkan produknya.

\section{DAFTAR PUSTAKA}

Achida Nur, M Mukery Warso, Leonardo Budi Hasiolan.2016. "Pengaruh Promosi, Harga, dan Desain Terhadap Keputusan Pembelian Sepeda Motor MIO GT" (Studi Empiris pada Produk Yamaha Mio GT di Weleri-Kendal)".Journal of Management.Vol.2.No.2.

Al-Qur'an Online.http;//www.dudung/net/quran-online/indonesia/49

Ashiddieqi Fuad, dan Mudiantono.2012. ”Analisis Pengaruh Harga, Desain Produk, dan Citra Merek Terhadap Keputusan Pembelian (Studi Kasus pada Produk Crooz. di Distro Ultraa Store Semarang)". Diponegoro Journal of Management.Vol.1.No.1.

Hamidah siti, dan Desi Anita.2013. "Analisis Persepsi Citra Merek, Desain, Fitur dan Pengaruhnya Terhadap Keputusan Pembelian Produk Handphone Samsung Berbasis Android (Studi Kasus STIE Pelita Indonesia)".Jurnal Ekonomi.Vol.21.No.4.

Justin Beneke, Ryan Flynn, Tamsin Greig and Melissa Mukaiwa. 2013. ”The Influece of Perceived Product Quality, Perception, Design and Risk on Customer Value and Willingness to Buy: a Study of Private label merchandise”. Journal Of Businnes and Industrial Marketing Vol.41 No.2 Hal (186-199).

Kotler phlip dan Amstrong Gary, 2015,Prinip - Prinsip pemasaran,edisi 12,Erlangga,Jakarta

Kotler Philip dan Keller Kevin, 2016,Manajemen Pemasaran,edisi 13 jilid 2,Jakarta

Mongi, Lidya mananeke.Li dan Repi, A. 2013. "Kualitas produk, Strategi promosi dan Persepsi harga pengaruhnya terhadap Keputusan Pembelian kartu simpati Telkomsel di Kota Manado”. Jurnal EMBA Vol.1 No.4 Desember 2013.

Sugiyono, 2016, "Metode Penelitian Kuantitatif, Kualitatif, dan R\&D" , Bandung: ALFABETA

Sujarweni,Wiratna. 2015. Statistik Untuk Bisnis dan Ekonomi.Edisi 1.Pustaka Baru Press. Yogyakarta. 